\title{
The Investigation of the Self-Efficacy Levels of Camp Leaders Working in the Youth
}

\author{
Şakir TÜFEKÇi' \\ Serkan DÜZ ${ }^{2}$ \\ ${ }_{1,2}^{1,2}$ Inonu University, Faculty of Sports Science, Malatya, Turkey. \\ 'E-mail:sakir.tufekci@inomu.edu.trTel:+904223410613
}

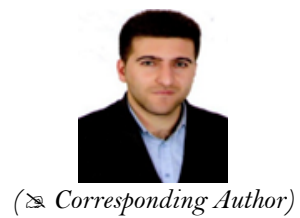

\begin{abstract}
This study was conducted to investigate the self-efficacy (SE) levels of camp leaders working in the youth camps under the Ministry of Youth and Sports. While the population of this descriptive type cross-sectional study was constituted by 1217 active camp leaders working in the youth camps, the sample was constituted by 400 active camp leaders. The personal information and the questionnaire form which composed of SE scale adapted into Turkish by Gözüm and Aksayan (1999) were used as data collection tools. Pearson's chi-square, independent-samples t-test and one-way ANOVA were used in the analysis of the data. Of the youth camp leaders $57.8 \%$ were over the age of $24,64.0 \%$ were male, $47.3 \%$ of their parents graduated from regular high school, $85.3 \%$ had social security, $68.5 \%$ came from core family structure, and income of $53.8 \%$ of the camp leaders was equal to their expenses. The mothers of $52.8 \%$ and fathers of $42.5 \%$ of the camp leaders graduated from primary school. $75.3 \%$ of camp leaders have been working in youth camps for $0-4$ years. It was determined that SE levels of the camp leaders were higher than the mean score and age, marital status, education level of the parents, income level of the family, duration of duty in the youth camp and status of doing sports were also the efficient factor. As a conclusion, it is advisable to organize activities and training programs to improve the SE levels of camp leaders.
\end{abstract}

Keywords: Self-efficiency, Self-efficacy, Level of self-efficacy, Youth camps, Camp leader, Ministry of youth and sports.

Citation | Şakir TÜFEKÇİ; Serkan DÜZ (2020). The Investigation of the Self-Efficacy Levels of Camp Leaders Working in the Youth. Asian Journal of Education and Training, 6(2): 278-283.

History:

Received: 4. February 2020

Revised: 6 March 2020

Accepted: 8 April 2020

Published: 21 May 2020

Licensed: This work is licensed under a Creative Commons

Attribution 3.0 License (cc)

Publisher: Asian Online Journal Publishing Group
Acknowledgement: Both authors contributed to the conception and design of the study.

Funding: This study received no specific financial support.

Competing Interests: The authors declare that they have no conflict of interests.

Transparency: The authors confirm that the manuscript is an honest, accurate, and transparent account of the study was reported; that no vital features of the study have been omitted; and that any discrepancies from the study as planned have been explained.

Ethical: This study follows all ethical practices during writing.

\section{Contents}

1. Introduction

2. Method

References... 


\section{Contribution of this paper to the literature}

This study contributes to the existing literature by investigating the self-efficacy levels of camp leaders working in the youth camps under the Ministry of Youth and Sports.

\section{Introduction}

Today, countries organize leisure time activities for the development of young people. The youth camps which organized by Ministry of Youth and Sports are also among those activities in Turkey. The activities in the youth camps which organized by the leadership of the Ministry of Youth and Sports have aimed to contribute to the overall development of the individuals participating in the camps and have undertaken as a mission to respond to the social, sporting, cultural and personal needs of these young people and to spread these activities throughout the country (Ministry of Youth and Sports, 2016b). Today, these camps stand out as facilities established to enable young people to evaluate their leisure time with various social, cultural and sportive activities. The purpose of the youth camp organized in Turkey are: to evaluate the time of the youth outside of the study and study areas, to provide relaxation, to contribute to their upbringing as individuals who are creative, productive, responsible, citizenship conscious, adopting and absorbing the principles and reforms of Atatürk (Ministry of Youth and Sports, 2005). The camp leaders have a critical importance in the preparation and execution of the activities organized in the camps, in controlling the attendance of the participants, in the provision of security and discipline, in the organization and order of the activity. Camp leaders provide guidance and consultancy to youths with their knowledge and experience as well as assisting programmers. Moreover, camp leaders both play an important role in educating young people through socio-cultural activities and on moral values and also helping young people to avoid bad habits by creating role models (Ministry of Youth and Sports, 2016a). Self efficacy (SE) is the individual's perception or judgment of successfully performing a certain action and controlling events or is the jurisdiction of the individual's capacity to achieve a certain level of performance (Gözüm \& Aksayan, 1999). If an individual's perception of self-efficacy is low, the individual will make less effort in a particular situation or to fulfill a responsibility (Harrison, Rainer, Hochwarter, \& Thompson, 1997). Therefore, it is thought that there is a significant interaction between leadership and level of SE. It is envisaged that the SE, which is defined as the belief that you will be successful in combating the difficulties encountered in different situations, is one of the most important determinants of leadership (Manojlovich, 2005). At the same time, camp leaders, whose task is to help and support young people attending in youth camps, need to be aware of their abilities and better show their potential. Therefore, it is important to know and develop the SE levels of camp leaders who working in youth camps that provide services to ensure the positive development of young people. The aim of this study was to investigate the SE levels of camp leaders who play an important role in youth camps and who have a critical importance in terms of the benefits they provide to young people.

\section{Method}

In this part of the study, the sample of the study, data collection tools and analysis of the data are presented.

\subsection{Research Model}

This study has descriptive type cross-sectional design and general screening model was used in the study. The general screening model is a research approach that aims to describe a situation that exists in the past or still as it exists (Karasar, 2005).

\subsection{Sample of the Study}

The population of study consisted of 1217 active leaders who working in the youth camps. The formula $\mathrm{Nt}^{2} \mathrm{pq} / \mathrm{d}^{2}(\mathrm{~N}-1)+\mathrm{t}^{2} \mathrm{pq}$ (Sümbüloğlu \& Sümbüloğlu, 2009) was used to determine the sample size that will represent the population. With a $95 \%$ confidence interval and $5 \%$ sampling error, the sample size of the study was calculated to be at least 383 participants and accordingly, 400 camp leaders were included in the study. Youth camp leaders are selected from people who have the skills and knowledge to work with a group of young people selected from physical education teachers, music teachers, other branch teachers, instructors experienced in theater, drama, folk dances, crafts and performing arts. Those who succeed in the courses and seminars opened by the General Directorate of Youth Services and Sports can serve as youth leaders (Ministry of Youth and Sports, 2005).

\subsection{Data Collection Tools}

The data were collected from youth camp leaders in the in-service training of the Ministry of Youth and Sports in April 2016. The questionnaire used in the study consists of two parts. In the first part, there are 23 questions including their personal information and the second part the SE scale which was developed by Sherer et al. (1982) and was adapted into Turkish by Gözüm and Aksayan (1999) were used. The SE was consisted of 23 items and four subscales such as initiating behavior, maintaining behavior, completing behavior and combating obstacles. Each item in the scale is scored on the 5-point Likert scale ranging from "It doesn't describe me at all (1)" to "It describes me very well (5)". Minimum 23, maximum 115 points can be obtained from the scale. The total score of SE was assessed as low for between 23 and 53 points, as middle for between 54 and 84 points, and as high for between 85 and 115 points. If the total score obtained from the scale was high, this means that the individual's perception of SE was at a good level. The Cronbach alpha internal consistency coefficient and the test-retest reliability of the Turkish version of the scale were found as 0.81 and 0.92 , respectively. In this study, the Cronbach alpha value was found as 0.86 .

\subsection{Data Analysis}

The data were analyzed by using PASW (SPSS version 18.0, Chicago, SPSS Inc.) statistics for Windows. As a result of the Kolmogorov-Smirnov normality test, Pearson chi-square, independent-samples t-test and one-way analysis of variance (ANOVA) with post-hoc correction was used to examine the differences between the 
independent variables and SE levels. Significance level was set as $\mathrm{p}<.05$.

\section{Findings}

The findings of the study are explained in detail in the tables below.

\begin{tabular}{|c|c|c|c|}
\hline Variables & & f & $\%$ \\
\hline \multirow{3}{*}{ Age (years) } & Between 19 and 23 & 169 & 42.2 \\
\hline & Between 24 and 28 & 173 & 43.3 \\
\hline & 29 and above & 58 & 14.5 \\
\hline \multirow{2}{*}{ Gender } & Female & 144 & 36.0 \\
\hline & Male & 256 & 64.0 \\
\hline \multirow{2}{*}{ Marital status } & Married & 49 & 12.2 \\
\hline & Single & 351 & 87.8 \\
\hline \multirow{6}{*}{ Education } & Regular High School & 189 & 47.3 \\
\hline & Anatolian High school & 99 & 24.8 \\
\hline & Vocational High School & 67 & 16.8 \\
\hline & Teacher High School & 13 & 3.3 \\
\hline & Sports High School & 8 & 2.0 \\
\hline & Other & 24 & 6.0 \\
\hline \multirow{3}{*}{ Income Level } & Income $>$ Expenditure & 83 & 20.8 \\
\hline & Income $=$ Expenditure & 215 & 53.8 \\
\hline & Income $<$ Expenditure & 102 & 25.5 \\
\hline
\end{tabular}

Table 1 showed the age, gender, marital status, education and income level of the camp leaders. It was seen that $58 \%$ of the camp leaders were over 24 years old, $64.0 \%$ of them were male, $87.8 \%$ were single, $47.3 \%$ were graduated from regular high school and $53.8 \%$ of the camp leaders' income was able to meet their expenses.

\begin{tabular}{l|l|c|c}
\multicolumn{4}{c}{ Table-2. Family characteristics of the camp leaders. } \\
\hline Variables & Illiterate & $\mathbf{f}$ & \% \\
\hline \multirow{4}{*}{ Education level of mother } & Literate & 37 & 9.3 \\
\cline { 2 - 4 } & Elementary education & 211 & 52.8 \\
\cline { 2 - 4 } & High school & 86 & 21.5 \\
\cline { 2 - 4 } & University & 20 & 5.0 \\
\hline \multirow{4}{*}{ Education level of father } & Illiterate & 10 & 2.5 \\
\cline { 2 - 4 } & Literate & 30 & 7.5 \\
\cline { 2 - 4 } & Elementary education & 170 & 42.5 \\
\cline { 2 - 4 } & High school & 112 & 28.0 \\
\cline { 2 - 4 } & University & 78 & 19.5 \\
\hline \multirow{2}{*}{ Mother's Occupation } & Working & 44 & 11.0 \\
\cline { 2 - 4 } & Not working & 223 & 89.0 \\
\hline \multirow{2}{*}{ Mother's Occupation } & Working & 177 & 45.8 \\
\cline { 2 - 4 } & Not working & & \\
\hline \multirow{2}{*}{ Note: f: Frequency, \%: Percentage. } & &
\end{tabular}

It was found that $52.8 \%$ of the mothers and $42.5 \%$ of fathers of the leaders graduated from the elementary school. While $89.0 \%$ of the mothers do not work, $55.8 \%$ of the fathers work Table 2 .

\begin{tabular}{|c|c|c|c|c|c|}
\hline & & $\mathbf{n}$ & $\overline{\mathrm{x}} \pm \mathrm{SD}$ & $t$ & $\mathbf{p}$ \\
\hline \multirow{2}{*}{ Gender } & Female & 144 & $82.6 \pm 13.5$ & \multirow{2}{*}{.684} & \multirow{2}{*}{.494} \\
\hline & Male & 256 & $83.5 \pm 13.9$ & & \\
\hline \multirow{2}{*}{ Marital status } & Single & 351 & $83.9 \pm 13.6$ & \multirow{2}{*}{-2.521} & \multirow{2}{*}{$.012^{*}$} \\
\hline & Married & 49 & $78.6 \pm 14.7$ & & \\
\hline \multirow{2}{*}{ Social security } & Yes & 341 & $82.7 \pm 14.1$ & \multirow{2}{*}{-1.783} & \multirow{2}{*}{.075} \\
\hline & No & 59 & $86.1 \pm 11.6$ & & \\
\hline
\end{tabular}

Note: ${ }^{*} \mathrm{p}<.05$.

In Table 3, it is observed that gender and social security was not an effective factor on SE ( $\mathrm{p}>.05)$, but the marital status was effective $(\mathrm{p}<.05)$. It was found that the $\mathrm{SE}$ scores of the single camp leaders were higher than those of married $(\mathrm{p}<.05)$.

\begin{tabular}{|c|c|c|c|c|c|}
\hline & & n & $\overline{\mathrm{x} \pm \mathrm{SD}}$ & $\mathbf{t}$ & p \\
\hline \multirow{2}{*}{ Mother } & Working & 44 & $80.8 \pm 13.3$ & \multirow{2}{*}{1.225} & \multirow{2}{*}{.221} \\
\hline & Not working & 356 & $83.5 \pm 13.9$ & & \\
\hline \multirow{2}{*}{ Father } & Working & 223 & $81.9 \pm 13.3$ & \multirow{2}{*}{2.142} & \multirow{2}{*}{$.033^{*}$} \\
\hline & Not working & 177 & $84.8 \pm 14.3$ & & \\
\hline
\end{tabular}

According to Table 4, only SE scores of camp leaders whose fathers are not working were higher than the those of father was working $(\mathrm{p}<.05)$. 
Table-5. Relationship between total SE scores and duty periods in the youth camp and status of doing sports

\begin{tabular}{l|l|c|c|c|c}
\hline \multicolumn{2}{|c|}{} & $\mathbf{n}$ & $\overline{\mathbf{x}} \pm \mathbf{S D}$ & $\mathbf{t}$ & $\mathbf{p}$ \\
\hline \multirow{2}{*}{ Duty periods in the youth camp } & O-4 years & 301 & $85.4 \pm 13.2$ & \multirow{2}{*}{5.686} & \multirow{2}{*}{$.00 *^{*}$} \\
\cline { 2 - 4 } & 5 years and above & 99 & $76.6 \pm 13.6$ & & \\
\hline \multirow{2}{*}{ Status of doing sports } & Yes & 238 & $85.0 \pm 13.5$ & \multirow{2}{*}{-3.676} & \multirow{2}{*}{$.000^{*}$} \\
\cline { 2 - 4 } & No & 133 & $79.6 \pm 13.4$ & \\
\hline
\end{tabular}

Note: ${ }^{*} \mathrm{p}<.05$

It was found that the SE score of the camp leaders working in the youth camp for 0-4 years was higher than those of working for 5 years and ebove, and the SE score of the camp leaders who do sports was higher than those who do not Table 5 .

Table-6. Relationship between total SE scores and the age and income of family of camp leaders.

\begin{tabular}{|c|c|c|c|c|c|c|}
\hline & & $\mathbf{n}$ & $\overline{\mathrm{x}} \pm \mathrm{SD}$ & $\mathbf{F}$ & p & post-hoc \\
\hline \multirow{3}{*}{ Age } & 1) 19-23 years old & 169 & $85.6 \pm 13.2$ & & \multirow{3}{*}{$.001^{*}$} & \multirow{3}{*}{$1>2,3$} \\
\hline & 2) 24-28 years old & 173 & $82.2 \pm 13.8$ & 7.215 & & \\
\hline & 3) 29 years and above & 58 & $78.5 \pm 14.0$ & & & \\
\hline \multirow{3}{*}{ Income level } & 1) Income > expenditure & 102 & $84.0 \pm 14.1$ & & \multirow{3}{*}{$.002 *$} & \multirow{3}{*}{$3>1,2$} \\
\hline & 2) Income = expenditure & 215 & $84.9 \pm 13.3$ & 6.324 & & \\
\hline & 3) Income $<$ expenditure & 83 & $79.1 \pm 14.0$ & & & \\
\hline
\end{tabular}

As seen in Table 6, total SE scores of the camp leaders between the ages of 19-23 were significantly higher than the others $(\mathrm{p}<.05)$. The SE scores of the camp leaders whose income of family were less than the expenditure were found to be significantly lower than the others $(\mathrm{p}<.05)$.

Table-7. Relationship between total SE scores and education level of the parents.

\begin{tabular}{|c|c|c|c|c|c|c|}
\hline & & $\mathbf{n}$ & $\overline{\mathrm{x}} \pm \mathrm{SD}$ & $\mathbf{F}$ & p & Post-hoc \\
\hline \multirow{5}{*}{ Education level of mother } & 1) Illiterate & 37 & $83.3 \pm 11.3$ & \multirow{5}{*}{3.078} & \multirow{5}{*}{$.016^{*}$} & \\
\hline & 2) Literate & 46 & $84.5 \pm 14.6$ & & & \\
\hline & 3) Elementary school & 211 & $84.8 \pm 13.7$ & & & $4<1,2,3,5$ \\
\hline & 4) High school & 86 & $78.8 \pm 14.2$ & & & \\
\hline & 5) University & 20 & $82.5 \pm 12.5$ & & & \\
\hline \multirow{5}{*}{ Education level of father } & 1) Illiterate & 10 & $86.6 \pm 9.9$ & \multirow{5}{*}{5.020} & \multirow{5}{*}{$.001^{*}$} & \\
\hline & 2) Literate & 30 & $84.6 \pm 13.6$ & & & \\
\hline & 3) Elementary school & 170 & $85.8 \pm 13.5$ & & & $4<1,2,3,5$ \\
\hline & 4) High school & 112 & $78.6 \pm 14.3$ & & & \\
\hline & 5) University & 78 & $83.0 \pm 12.8$ & & & \\
\hline
\end{tabular}

When the total SE scores of the camp leaders were examined according to the education level of the parents, it was seen that $\mathrm{SE}$ scores of the camp leaders whose parents graduated from high school were lower than those of other leaders' parents Table $7(\mathrm{p}<.05)$.

\section{Discussion}

The purpose of this study was to investigate the SE levels of camp leaders who play an important role in youth camps and who have a critical importance in terms of the benefits they provide to young people. At the end of the study age, marital status, education level of the parents, income level of the family, duty period in the youth camps and the status of doing sports were found to be effective factors on the SE level of the camp leaders. When the findings analyzed, $42.2 \%$ of the camp leaders who participated in the study were 19-23 years old, $43.3 \%$ of them were 24-28 years old and $14.5 \%$ of them were 29 years old and above Table 1 . Similarly, in the study of Coban and Coșkuner (2010) $36.7 \%$ of the leaders in youth camps were between $18-24$ years old, $34.0 \%$ of them were between the ages of $18-24,34.0 \%$ between the ages of $25-29$, and $29.3 \%$ were 30 years old and above. According to the findings of the study, age was found as an effective factor on the SE score and SE score of the camp leaders aged 19-23 years old were found higher than the older age groups. When the literature is examined, it is seen that there are different findings. Gözüm and Aksayan (1999) has stated that a person gained more experience with the progress of the age and this constitute an important source of increase in SE score. Similarly, Keskin and Orgun (2006) and Uz and Kitiș (2017) has reported that SE scores of the physical education students changed positively as the age increased. Sari, Yenigün, Alt1nc1, and Oztürk (2011) stated that SE score of the youths aged between 1820 years was higher than those of older age groups, but the difference between them is not statistically significant. In the study of Yigitbas and Yetkin (2003) and Uğur (2010) while the age was not found to be an effective factor on SE, Taș and Akın (2018) showed that SE score has decreased significantly as the age progressed.

In this study, $64.0 \%$ of the camp leaders were male and $36.0 \%$ were female. In line with our findings, Coban and Coșkuner (2010) reported that $61.3 \%$ of the leaders were male and $38.7 \%$ were female. In the study of Kartal, $56.3 \%$ of the program managers in the youth camp were male and 43.7\% were female (Kartal \& Temel, 2016). According to the results of this study, gender was not found to be an effective factor on the SE level. The findings of Yigitbas and Yetkin (2003); Keskin and Orgun (2006); Karadağ, Aksoy, and Ucuzal (2011); Akgül and Güngör (2016); Ozpulat (2016) and Taș and Akın (2018) support our findings. Unlike our findings, the SE score of female students was found statistically higher than those of male students in the study of Otacığlu (2008); Sari et al. (2011) and Kızılc1, Mert, Küçükgüçlü, and Yardımc1 (2015). These results can be interpreted as the number of people who 
believe that they should have equal responsibility for both sexes nowadays.

Marital status was determined as an effective factor on the SE score. It was found that the SE score of single camp leaders were higher than those of the married ones. The study of Taș and Akın (2018) was similar to our findings. However, in the study of Akgül and Güngör (2016) although the SE score of single leaders were higher than those of the married ones, there were no statistically significant difference. Similarly, Kulakçı, Ayyıld1z, Emiroğlu, and Köroğlu (2012) found that the SE level of married individuals were higher than those of the singles.

There was no statistically significant difference between social security status and the SE scores of camp leaders who participated in the study. When the working status of the parents was examined, there was no statistically significant difference found between the SE scores of the camp leaders whose mother were working or not. However, SE scores of the camp leaders whose father was not working were higher than the ones whose father was working $(\mathrm{p}<.05)$.

In this study, when the SE level was examined it was found that total SE score of the camp leaders whose parents graduated from high school were lower than those of other leaders' parents $(p<.05)$. It is known that as the level of education increases, the level of knowledge and sensitivity of the individual increases. Therefore, the individual can recognize the activating stimuli and the level of SE increase. However, it seems that our findings do not interestingly support this information. In the study of Taş and Akın (2018) study, unlike our findings, the parents of students with the highest SE scores were reported to be university graduates. Similarly, Uğur (2010) found that the SE scores of the parents of students with a university degree had significantly higher than others. As a different finding, Ozkahraman and Y1ld1r1m (2012) reported no significant difference between the education level of the parents and the SE scores.

When the SE scores of the camp leaders and the family income were compared, it is found that the SE scores of the camp leaders whose family income is less than the expenditure are significantly lower than the others $(p<.05)$. Based on these findings, it can be said that the reason of the low SE score of the individuals whose income is less than the expenditure is due to lack of self-confidence and abstaining behaviors. Taș and Akın (2018) also supports our findings. However, Akgül and Güngör (2016) and Ozpulat (2016) reported that the level of family income was not an effective factor on the SE scores.

In the study, $75.3 \%$ of the camp leaders who participated in the study stated that they have worked in youth camps for 0-4 years and $24.8 \%$ of them have worked for 5 years and above. Coban and Coşuner (2010) reported that $66.7 \%$ of the leaders worked in youth camps for $1-3$ years and $33.3 \%$ of them worked for 4 years and above. It has been determined that camp leaders who have worked in the youth camps for 0-4 years had a higher SE score than those of worked for 5 years and above. This result may be due to the fact that camp leaders are young, are new to the task, are excited and are more idealistic. The reason for the decrease of SE scores as the duration of the camp leaders increases, may be attributed to the low motivation due to the different expectations of the leaders or not meeting their expectations regarding the camp conditions. However, there are studies indicating that SE scores increase with the increase in the term of duty (Akgül \& Güngör, 2016; Uz \& Kitiș, 2017).

SE scores of the camp leaders who do sports found higher than those who did not in this study. Sports not only helps people feel better and keep fit via movement, but also helps develop qualities they can use in life, such as struggling with difficulties (Ozkahraman \& Y1ld1rım, 2012). Ryckman, Robbins, Thornton, Gold, and Kuehnel (1985) also stated that if the individual is physically fit and healthy, the individual's perception affected the SE scores positively (Ozen, Olçücü, Ozen, \& Demirel, 2014). It was seen that people who had high SE score attended regular and continuous exercise programs to achieve a certain purpose. Similarly, Sezer, Ișgör, Ozpolat, and Sezer (2006). reported that the people who do not exercise or who do not have the opportunity to do exercise had a low SE level (Sezer et al., 2006).

As a result, age, marital status, education level of the parents, income level of the family, duty period in the youth camps and the status of doing sports were found to be effective factors on the SE level of the camp leaders. Therefore, in order to keep the motivations of the camp leaders working in youth camps alive and continue their duties, it may be recommended to follow their wishes and expectations regularly and increase their wages. As a conclusion, it is advisable to organize activities and training programs to improve the SE levels of camp leaders.

\section{References}

Akgül, G. N., \& Güngör, G. (2016). Healthy lifestyle behaviors and self-efficacy levels of health care professionals working at primary health care institutions. Journal of Research and Development in Nursing, 18(1), 14-27.

Coban, B., \& Coşkuner, Z. (2010). Analysis of national education ministry youth camps' participant satisfaction. e-Journal of Nerw World Sciences Academy, 5(1), 16-27.

Gözüm, S., \& Aksayan, S. (1999). The reliabillty and valldity of Turkish form of the self-efficacy scale. Ataturk University Journal of Nursing School, 2(1), 21-34.

Harrison, A. W., Rainer, J. R. K., Hochwarter, W. A., \& Thompson, K. R. (1997). Testing the self-efficacy-performance linkage of socialcognitive theory. The Journal of Social Psychology, 137(1), 79-87.Available at: https://doi.org/10.1080/00224549709595415.

Karadağ, E., Aksoy, D., \& Ucuzal, M. (2011). The self-efficacy-sufficiency levels of a health college student. Maltepe University Nursing Science and Art e-Journal, 4(1), 13-20.

Karasar, N. (2005). Scientific research method. Ankara: Nobel Publishing.

Kartal, M., \& Temel, C. (2016). Examining the communication and problemsolving skills of the youth camp program supervisors. European Journal of Physical Education and Sport Science, 2(2), 39-49.

Keskin, G., \& Orgun, F. (2006). Studying the strategies of students' coping with the levels of self-efficacy-sufficiency. Anatolian Journal of Psychiatry, 7(2), 92-99.

Kızılcı, S., Mert, H., Küçükgüçlü, Ö., \& Yardımcı, T. (2015). Examination of self-efficacy levels of nursing faculty students in terms of gender. Dokuz Eylul University Faculty of Nursing Electronics Journal, 8(2), 95-100.

Kulakçı, H., Ayyıldız, T., Emiroğlu, O., \& Köroğlu, E. (2012). Evaluation of the self-efficacy perceptions and healthy lifestyle behaviors of elderly people living in nursing home. Dokuz Eylul University Faculty of Nursing Electronics Journal, 5(2), 53-64.

Manojlovich, M. (2005). Promoting nurses' self-efficacy: A leadership strategy to improve practice. JONA: The Journal of Nursing Administration, 35(5), 271-278.Available at: https://doi.org/10.1097/00005110-200505000-00011.

Ministry of Youth and Sports. (2016b). Youth camps unit. Retrieved from: https://genclikkamplari.gsb.gov.tr.

Ministry of Youth and Sports. (2005). GSGM youth camps leaders guide. Ankara: Youth Services Department. 
Ministry of Youth and Sports.. (2016a). Touth camps program officers orientation meeting study note. Ankara: Youth Services General Directorate.

Otacıoğlu, S. (2008). A research concerning the level of self efficacy-sufficiency of the apprentices in music teaching who took a part in the test of school experience I. Cumhuriyet University Journal of Social Sciences, 32(1), 163-170.

Ozen, G., Olçücü, B., Ozen, Ş., \& Demirel, N. (2014). The effect of mountain climbing training and summit climbing on the perception of selfefficacy. International Journal of Turkish Education Sciences, 2(3), 131-136.

Ozkahraman, Ş., \& Yıldırım, B. (2012). Determination of nursing and midwifery students' core comptencies. Journal of Research and Development in Nursing, 14(3), 53-65.

Ozpulat, F. (2016). The relationship between self-efficacy level and gender perception of university students: Beyşehir example. Journal of Human Sciences, 13(1), 1222-1232.Available at: https://doi.org/10.14687/ijhs.v13i1.3570.

Ryckman, R. M., Robbins, M. A., Thornton, B., Gold, J. A., \& Kuehnel, R. H. (1985). Physical self-efficacy and actualization. Journal of Research in Personality, 19(3), 288-298.

Sari, I., Yenigün, O., Altıncı, E., \& Oztürk, A. (2011). Effect of satisfaction of the basic psychological needs on general self-efficacy and trait anxiety (Example of Sakarya University department of sport management). Spormeter Journal of Physical Education and Sports Sciences, 9(4), 149-156.

Sezer, F., Işgör, I., Ozpolat, A., \& Sezer, M. (2006). Investigation of high school students' self-efficacy levels in terms of some variables. Journal of Kazım Karabekir Education Faculty, 13(1), 129-137.

Sherer, M., James, E. M., Blaise, M., Steven, P.-D., Beth, J., \& Ronald, W. R. (1982). The self-efficacy scale: Construction and validation. Psychological Reseach, 51(2), 663-671.Available at: https://doi.org/10.2466/pro.1982.51.2.663.

Sümbüloğlu, K., \& Sümbüloğlu, V. (2009). Biostatistics. Ankara: Hatipoğlu Publishing.

Taş, F., \& Akın, B. (2018). The association of health promotion life -style and self-efficacy sufficiency with socio-economic status. Health and Society, 28(2), 24-18.

Uğur, E. (2010). Nurse managers' coaching skills and self efficacy believes. Master thesis. Marmara University, Istanbul.

Uz, D., \& Kitiş, Y. (2017). Determination of healthy life style behaviors and self-efficacy of nurses working in a hospital. Gazi University Journal of Health Sciences, 2(3), 27-39.

Yigitbas, C., \& Yetkin, A. (2003). Evaluating of selfefficacy-sufficiency levels of students in the health college. Cumhuriyet University Nursing Journal, 7(1), 6-13. 